\title{
Use of antifungal principles from garlic for the inhibition of yeasts and moulds in fermenting green olives
}

\author{
By A. Asehraou², S. Mohieddine ${ }^{3}$, M. Faid ${ }^{* 1}$ and M. Serhrouchni ${ }^{2}$ \\ 1Hassan II Institute of Agronomy and Veterinary Medicine. P. O. Box 6202 Rabat-Instituts, Morocco. Fax: 7674929. \\ 2Département de Biologie, Faculté des Sciences, Oujda, Morocco
}

\section{RESUMEN}

Uso de fungicidas del ajo para la inhibición de levaduras y mohos en aceitunas verdes en fermentación.

En el trabajo se evalúa la contaminación por levaduras en la fermentación de aceitunas verdes. Se hicieron recuentos en placas, y se aislaron, identificaron y caracterizaron las cepas correspondientes. Los resultados indican que los recuentos de mohos alcanzan el máximo cuando la acidez es elevada. Las especies más abundantes fueron: Pichia anomala, Debaryomyces hansenii, Candida versatilis y $C$. tropicalis. Las especies anteriores se usaron en ensayos de inhibición in vitro utilizando medios de cultivos con ajo, extracto acuoso y aceites obtenidos por arrastre de vapor, determinándose las concentraciones de inhibición mínima (MICs). Las concentraciones que mostraron actividad no tuvieron inhibición frente a las bacterias lácticas. El aceite esencial fue la composición más activa frente a mohos y levaduras. La utilización adicional de ácido sórbico durante la fermentación y almacenamiento dio lugar a un descenso en la población de levaduras.

PALABRAS-CLAVE: Aceituna verde - Ajo - Fermentación Fungicida - Inhibición - Levadura - Moho.

\section{SUMMARY}

Use of antifungal principles from garlic for the inhibition of yeasts and moulds in fermenting green olives.

Yeast contamination of fermented green olives was evaluated. Plate counts were determined during the fermentation process and strains were isolated, identified and characterized. Results showed that counts of yeasts reached a maximum when the acidity was rather high. Strain identification showed that: Pichia anomala, Debaryomyces hansenii, Candida versatilis and $C$. tropicalis were the most abundant species. Isolates of these species were used in the in-vitro inhibition assays using laboratory media with whole garlic, water extract and steam distilled oil to determine the Minimal Inhibitory Concentrations (MICs). The effect of concentrations that inhibited yeasts and moulds were also studied on lactic acid bacteria which were not inhibited. The essential oil was the most active on growth of moulds and yeasts. The same concentrations of sorbic acid were used in olive preservation against yeasts and moulds during the fermentation and storage. $A$ net decrease in yeast counts was observed.

KEY-WORDS: Antifungal - Fermentation - Garlic - Green olive - Inhibition - Mould - Yeast.

\section{INTRODUCTION}

The role of yeasts in green olive fermentation is not precised with accuracy. In fact, yeasts may be considered as undesirable microorganisms in green olives fermentation because of quality deterioration of the fermented product when they grow on brine surfaces. The fermentation procedure adopted in Morocco usually results in film formation in high capacity fermentors. Part of the fermenting olives may undergo spoilage. However, the film formation by yeasts and moulds may constitute a barrier to the air (oxygen) to enter the brine and can help developping the fermentation by creating a suitable environment for lactic acid bacteria (LAB). Unfortunately, the presence of yeasts and moulds may lead to enzymes formation such as cellulase and pectin-lyase which may diffuse in the brine and cause some deteriorations to the fermenting olives.

Several plants are now known for their antibacterial (Beylier, 1979) and/or antifungal (Bonchrid and Flegel, 1984) properties. The use of these plants entirely or their extracts are prefered to synthetic preservatives in the field of food preservation (Faid et al, 1995). In a previous study we showed that when the whole plant was used, the activity was greater than the steam distillation oil (Faid et al, 1995). In some cases the entire plant is not easy to handle and not practical for the user. Therefore, oils are often used as the active compunds of the various plants. In the case of olive fermentation the whole plant can be used in the fermentors since there is no activity on lactic acid bacteria at the concentration that would inhibit yeasts.

In the present study, yeasts and moulds involved in the film formation were isolated, identified, and applied in inhibition assays by garlic principles in the laboratory to prevent the film formation and growth of yeasts and moulds during fermentation. 


\section{MATERIALS AND METHODS}

\section{Olive preparation}

Green olives of the picholine variety were prepared according to the method described by Faid et al., (1994). Samples were taken from the brine and the upper surface of the fermentor for chemical and microbiological determinations.

\section{Chemical determinations}

$\mathrm{pH}$ values of brines were determined by using a Crison micro $\mathrm{pH} 2000 \mathrm{pH}$-meter. The titratable acidity was determined by titrating $10 \mathrm{ml}$ of brine with a N/10 sodium hydroxyde solution until the $\mathrm{pH}$ reach 8.5 measured by the $\mathrm{pH}$-meter. Results are expressed in percent lactic acid.

\section{Microbiological methods}

Ten $\mathrm{ml}$ of brine were added to $90 \mathrm{ml}$ of sterile saline water $(8.5 \mathrm{~g} / \mathrm{l})$ and appropriately diluted up to $10^{-6}$ for a surface plating procedure on Potato-Dextrose-Agar (Difco Laboratories, USA) acidified to $\mathrm{pH} 3.5$ with sterile lactic acid. The plates were incubated at $28^{\circ} \mathrm{C}$. Yeast colonies were counted on the medium after 3 days.

Sixty five yeast isolates were picked at random from the PDA plates used for the viable counts. The isolates were subcultured before being identified according to the simplified key for the identification of food yeasts described by Deak and Beuchat (1987).

\section{Plant materials preparation}

\section{Water plant}

The whole garlic was peeled and cleaned with sterile distilled water. The material was then blended in a UltraTurrax type blender with the same volume of sterile distilled water. The obtained slurry was incorporated directly in culture media (see below).

\section{Water extract}

$10 \mathrm{~g}$ of red garlic were mixed with $60 \mathrm{~mL}$ of hot water $\left(90^{\circ} \mathrm{C}\right)$, allowed to stand for $15 \mathrm{~min}$ (the mixture was shaken every 2 to $3 \mathrm{~min}$ ) and filtered on filter paper Whatman $\mathrm{N} .-4$. The aqueous extract was allowed to cool to $40^{\circ} \mathrm{C}$ and mixed with the culture media (see in vitro inhibition).

\section{Steam distillation}

Individual fresh plants were steam distilled to isolate their essential oils. Amounts of 200 to $250 \mathrm{~g}$ of garlic were introduced in the distillation flask $(1 \mathrm{~L})$ which was connected to a steam generator via a glass tube and to a condenser to retrieve the oil. This was recovered in a funnel tube. Steam was applied for 3 hours and the recovered mixture was allowed to settle and the oil was withdrawn

\section{In vitro inhibition assays}

The different preparation were incorporated in culture media respectively: PDA for yeasts and moulds, PCA for Gram negative bacteria and MRS for lactic acid bacteria. The concentrations used were as bellow:

whole garlic (\%) $0.2,3,5$

Aqueous extract (\%) 1, 1.6, 2, 4, 10, 20

Essential oil (ppm) 20, 40 100, 140, 200

Sorbic acid (\%) 0.01, 0.02, 0.05, 0.06, 0.075, 0.1

The plates were spot inoculated with the isolates and incubated at $30^{\circ} \mathrm{C}$. The growth was examined every day during 1 week. Growth or no growth of the different strains was used to evaluate the inhibition.

\section{Inhibition assays on olives}

A bulk of green olives was divided into 3 portions of $25 \mathrm{~kg}$ each which were dispensed in $50 \mathrm{~L}$ sterilized jars. The trials were performed as follow:

Trial N. .1 : Green olives (control)

Trial N. .2 : Green olives in presence of:

- sorbic acid (0.075) + aqueous extract of garlic $(10 \%)$.

Trial N.. 3: Green olives in presence of:

- sorbic acid $(0.075 \%)+$ garlic essential oil $(200$ ppm).

The flasks were tightly closed and incubated at ambient temperature $\left(22^{\circ} \mathrm{C}\right)$. Yeast counts were followed up for 3 months and the assays were carried out in duplicate.

\section{RESULTS AND DISCUSSION}

Viable counts of Yeasts.

Figure 1 shows the yeast counts increase during the fermentation process of green olives. Maxima were reached after 11 days and 18 days respectively for the 2 trials. These maxima were maintained at the same level or decrease slightly. Yeasts may represent the most frequent spoilage microorganisms in the olives prior to fermentation (Faid et al., 1994). The high levels of yeasts in the raw material may have an effect on the quality of olives during fermentation and during storage if no heat treatment is applied to the fruits. Similar results were reported by Asehraou et al., (1993) on yeast counts in fermenting green olives. Both yeasts in the brine and in the surface film were high in most samples. 


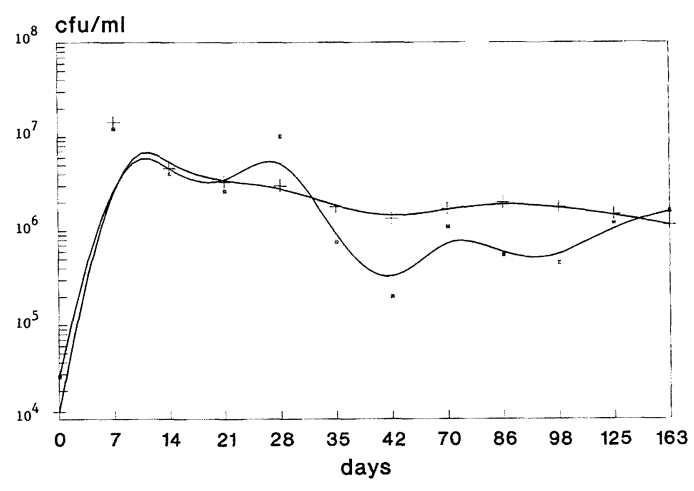

Figure 1

Growth pattern of the natural contaminating yeasts in olives during fermentation.

$(+)$ debittered olives $(\bullet)$ non debittered olives

Olives are sold in bulk in Morocco. This may suppose that no heat treatment is applied to olives which are exhibited in open containers. A high level contamination in yeasts is undesirable for the product. These microorganisms would cause some defects in the product leading to abnormal odors and colors of the fruits.
Some yeast species can use the lactic acid as a source of carbone which may result in a $\mathrm{pH}$ increase and consequently the product is susceptible to spoilage by bacteria species such as Bacillus, Pseudomonas and Clostridium. Some other species can release cellulose and pectin dgrading enzymes and make the fruit soften and spoilt during fermentation and/or storage.

Table I shows the most frequent species of yeasts identified in olives. Some species are very common in the olive contamination as it was reported by some authors (Faid et al., 1994) and may have an effect on the technology of the fermented green olives. Among the species widely distributed in high sodium chloride concentrations in brines, Debaryomyces and Pichia. These two groups have a potent role in the film formation with moulds. Strains belonging to Debaryomyces had some interesting properties including growth in presence of high sodium chloride concentrations up to $12-15 \%$, growth at $37^{\circ} \mathrm{C}$, the use of nitrate and urea, and the hydrolysis of lipids (lipase). The other species belonging to Pichia are also highly represented. Pichia species are oxydative yeasts known by growth on the surface of brines and fermenting liquids. Pichia strains can use lactic acid as a source of energy leading to a decrease of the acidity which is a dangerous phenomena for the fermentation. This may result in developement of the undesirable microorganisms which were inhibited by the acidity.

Table I

Yeast and moulds distribution in fermenting olives (NAT: non alkali treated; AT: alkali treated)

\begin{tabular}{|c|c|c|c|c|c|c|c|c|}
\hline & \multicolumn{4}{|c|}{ Brine } & \multicolumn{4}{|c|}{ Film } \\
\hline & \multicolumn{2}{|c|}{ NAT } & \multicolumn{2}{|c|}{ AT } & \multicolumn{2}{|c|}{ NAT } & \multicolumn{2}{|c|}{ AT } \\
\hline & $\mathbf{n b}$ & $\%$ & nb & $\%$ & $\mathbf{n b}$ & $\%$ & nb & $\%$ \\
\hline \multicolumn{9}{|l|}{ YEASTS } \\
\hline C. tropicalis & 6 & 9 & 12 & 18.8 & 0 & 0 & 1 & 3.7 \\
\hline C. versatilis & 9 & 13.4 & 2 & 3.1 & 0 & 0 & 0 & 0 \\
\hline C. rugosa & 2 & 3 & 1 & 1.6 & 0 & 0 & 0 & 0 \\
\hline C. tenuis & 1 & 1.5 & 1 & 1.6 & 0 & 0 & 0 & 0 \\
\hline C. etchellsii & 1 & 1.5 & 3 & 4.7 & 4 & 11.1 & 0 & 0 \\
\hline P. anomala & 14 & 21 & 11 & 17.2 & 3 & 8.3 & 0 & 0 \\
\hline P. membranaefaciens & 1 & 1.5 & 4 & 6.3 & 4 & 11.1 & 6 & 22.2 \\
\hline D. hansenii & 8 & 12 & 8 & 12.5 & 2 & 5.6 & 2 & 7.4 \\
\hline S. cerevisiae & 2 & 3 & 2 & 3.1 & 0 & 0 & 1 & 3.7 \\
\hline \multicolumn{9}{|l|}{ MOULDS } \\
\hline Geotrichum & 23 & 34.3 & 20 & 31.3 & 22 & 61.1 & 15 & 55.6 \\
\hline Penicillium & 0 & 0 & 0 & 0 & 1 & 2.8 & 2 & 7.4 \\
\hline Total & 67 & 100 & 64 & 100 & 36 & 100 & 27 & 100 \\
\hline
\end{tabular}


Table II

Inhibitory activities of whole garlic on the various microorganisms

\begin{tabular}{lcccc}
\hline Micro & Number & $\mathbf{0 . 2}^{\boldsymbol{*}}$ & $\mathbf{3}$ & $\mathbf{5}$ \\
\hline Yeasts & 15 & 0 & 86.6 & 100 \\
Moulds & 7 & 14.2 & 100 & 100 \\
Gram - & 7 & 0 & 57.1 & 100 \\
LAB & 13 & 0 & 15.38 & 15.38 \\
\hline
\end{tabular}

Micro: Microorganisms*: in percent

Figures are percent of strains inhibited

Results showing the effect of whole garlic on yeast growth are reported in table II. Partial inhibition was seen with a 3\% (13 isolates out of 15 were inhibited totally). At $5 \%$ all of the isolates were inhibited. There was a net effect of garlic on the growth of yeasts on PDA, but conditions for the application of garlic in food preservation is to be studied for additional data because of the strong odor that can not be accepted in all foodstuffs.

Moulds were more sensitive than yeasts and a 3\% content in PDA could inhibit totally all the strains (table II). It would be very interesting to prevent hygienic problems due to mycotoxins formation (Tantaoui-Elaraki and Letutour, 1985). Lactic acid bateria were not inhibited by garlic and only slight inhibition was observed with a $5 \%$ concentration. This is the most important finding which may lead to a possible application of garlic as a preventing agent against yeasts and moulds directly in the fermentation process of green olives. Since LAB were not inhibited by the concentration that had totally inhibited yeasts and moulds, the addition of garlic in the fermentor would not disturb the fermentation process and may prevent in the same time mould and yeast growth.

The antifungal activity of garlic was studied in vitro and this is the most known approach in studying the inhibition activity of principles in plants. Studies to concern the application of garlic to some food systems is seldom. It would be more interesting to exploit the natural preservation by the use of antifungal properties of garlic or its extracts.
Inhibition tests using aqueous extract showed a MIC of $10 \%$ (table III). This is very interesting for the preservation of such foods since garlic can be used as a natural preservative and flavouring agent. The aqueous extract of garlic is easier to handle and also to apply in olive fermentation than any other coumpound. The concentration that had inhibited the whole strains was relatively high. This would depend on the initial amount used for the preparation of the extract.

Table IV shows the inhibitory activities of garlic essential oil against microorganisms. One can figure out that yeasts and moulds are the most sensitive to garlic principles especially the essential oil. Inhibition seen with whole garlic would be due mostly to the essential oil. The use of garlic as an antifungal inhibitior in food systems is questionable. Hence, the organoleptic changes by the strong flavour of garlic would not encourage the use of this plant in food preservation but in olives the organoleptic change may not constitute a major problem since in traditional fementations garlic is used as flavouring agent more than for the inhibitory activities.

Antimicrobial activities of various essential oils was deeply studied but little is known on garlic essential oil. Basically plant essential oils were found to be more inhibitory to moulds and yeasts than bacteria (Charai et al., 1995). This property is very interesting since in food fermentations yeasts and moulds which are the main

Table III

Antimicrobial activity of the water extract of garlic

\begin{tabular}{lrlccccc}
\hline Micro & Number & $\mathbf{1}^{\text {* }}$ & $\mathbf{1 . 6}$ & $\mathbf{2}$ & $\mathbf{4}$ & $\mathbf{1 0}$ & $\mathbf{2 0}$ \\
\hline Yeasts & 15 & 0 & 6.6 & 40 & 86.6 & 100 & 100 \\
Moulds & 7 & 0 & 57 & 85.7 & 100 & 100 & 100 \\
Gram & 7 & 0 & 0 & 28.5 & 85.7 & 100 & 100 \\
LAB & 13 & 0 & 0 & 7.7 & 7.7 & 15.38 & 15.38 \\
\hline
\end{tabular}

Micro: Microorganisms*: in percent

Figures are percent of strains inhibited 
Table IV

Inhibition assays on microorganisms of the essential oil of garlic

\begin{tabular}{lrrrrrr}
\hline Micro & Number & $\mathbf{2 0}$ & $\mathbf{4 0}$ & $\mathbf{1 0 0}$ & $\mathbf{1 4 0}$ & $\mathbf{2 0 0}$ \\
\hline Yeasts & 15 & 0 & 73.3 & 93.3 & 93.3 & 100 \\
Moulds & 7 & 0 & 85.7 & 85.7 & 100 & 100 \\
Gram - & 7 & 0 & 57.1 & 71.4 & 100 & 100 \\
LAB & 13 & 0 & 7.7 & 7.7 & 23 & 23 \\
\hline
\end{tabular}

Micro: Microorganisms*: in ppm

Figures are percent of strains inhibited

microoganisms that would grow in the association of lactic acid bacteria and cause some deteriorations related to the organoleptic quality and/or food safety, can be destroyed without affecting the growth of the acidifying microbiota.

Inhibition tests using sorbic acid showed a MIC of 0.05 for four strains and less than $0.25 \%$ for 1 strain (table V). One can figure out that these concentrations are in the range of limits allowed in processed dried foods $(0.15$ to $0.3 \%)$.

Antimicrobial activities of sorbic acid have been intensively studied (Restaino et al., 1982; Sofos and Busta, 1982; Zamora and Zaritzky, 1987). Sorbic acid is used in dried foods (Busta, 1982; Sofos, 1981). The concentration of sorbic acid may not exceed $0.2 \%$ in most foods. The replacement of chemicals in foods by natural preservatives is suitable for more safety. But when it is not possible, a low concentration is preferred.

Sorbic acid is more active on yeasts and moulds in low $\mathrm{pH}$ foods. This property is very interesting since in low $\mathrm{pH}$ foods yeasts and moulds are the main microorganisms that would grow and cause some deteriorations related to the organoleptic quality and/or food safety. This property is to be exploited in fermenting olives since the $\mathrm{pH}$ is low and may allow more inhibition of yeasts and moulds which are the most abundant. The most relevant problem related to olive spoilage comes from yeast and mould contamination.

The use of natural inhibitors combined with chemical inhibitors may decrease the inhibitory concentration of the chemical preservatives. The use of natural plants and or spices in food preservation should be encouraged to lower the toxicity of some foods because of the high concentrations used. Research in this field is still at a preminum and more investigations are required to reduce the use of sorbic acid and related chemicals.

Experiments were applied to 3 bulks of green olives (25 kg each) which were treated with garlic (the amounts used were the MICs found in the «in vitro» assays) and stored at ambient temperature. Yeast counts after one month are reported in figure 2 . These showed that yeast levels were reduced in the 3 trials after one month. There was no yeast growth during the following the 3 months of storage after the last sample was taken. A clear difference was observed between trials and the control as it is showed in figure 2 . This may give the evidence that the inhibiting systems used in our experiments could be a succesful mean for the preservation of olives against yeasts contamination.

Upon the forgoing, the use of natural inhibitors combined with chemical inhibitors may decrease the inhibitory concentration of the chemical preservatives. The use of natural plants and or spices in food preservation should be encouraged to lower the toxicity of some foods because of the high concentrations used. Research in this field is still at a preminum and more investigations are required to reduce the use of sorbic acid and related chemicals.

Table V

Antimicrobial activity of sorbic acid on the various microorganisms

\begin{tabular}{lrllcccc}
\hline Micro & Number & $\mathbf{0 . 0 1 ^ { * }}$ & $\mathbf{0 . 0 2}$ & $\mathbf{0 . 0 5}$ & $\mathbf{0 . 0 6}$ & $\mathbf{0 . 0 7 5}$ & $\mathbf{0 . 1}$ \\
\hline Yeasts & 15 & 0 & 0 & 33.3 & 53.3 & 100 & 100 \\
Moulds & 7 & 0 & 0 & 42.8 & 57.7 & 100 & 100 \\
Gram & 7 & 0 & 0 & 0 & 28.5 & 28.5 & 28.5 \\
LAB & 13 & 0 & 0 & 0 & 0 & 0 & 15.38 \\
\hline
\end{tabular}

Micro: Microorganisms*: in percent

Figures are percent of strains inhibited 


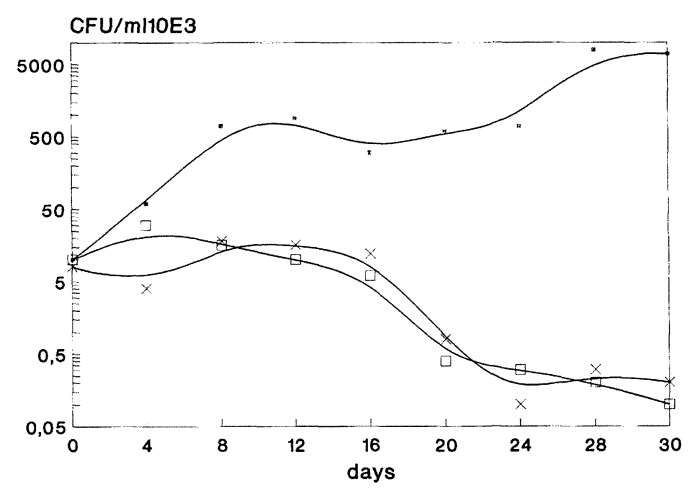

Figure 2

Inhibition pattern of yeasts in presence of the inhibiting systems. (x) Sorbic acid + water extract ( $\square$ ) Sorbic acid + essential oil $(\bullet)$ control

\section{REFERENCES}

Asehraou, A., and Faid, M. (1993). - «Fermentation des olives vertes désamérisées".- Actes Inst. Agron. Vet. 13, (2) 2126.

Bachmann, F. M. (1961). - «The inhibiting action of certains species on the growth of microorganisms"-. J. Indust. Eng. Chem. 8, 620-623.

Beylier, M. F. (1979). - -Bacteriostatic activity of some Australian essential oils"-. Perfum. Flav. 4 (2), 23-25.

Bonchird C. and Flegel T. W. (1984). - «In vitro antifungal activity of eugenol and vanillin against Candida albicans and Cryptococcus neoformans"-. Can J. Microbiol. 28, 12351241.

Busta, F. F. (1982). - «Combined effects of sorbic acid and other inhibitory factors in cured meat products»-. Food Technol. in Australia 34, 529-531.
Charai M. Mosaddak M. and Faid M. (1996). - Chemical composition and antimicrobial activities fo two aromatic plants: Origanum majorana L. and O compactum»-. J. Ess. Oils. Res.

Deak T. and L. R. Beuchat (1987). - «Identification of Foodborne yeasts»-. J. Food Prot 50, 243-264.

Faid M. Bakhy K., Anchad M., and Tantaoui-Elaraki A. (1995). - «Almond paste: Physico-chemical and microbiological characterization and preservation with sorbic acid and cinnamon»-. J. Food Prot 58 (5) 547-550.

Faid, M., Akhartouf R. and Asehraou A. (1994). - «Microorganisms associated with post-harvest green olives deteriorations in Morocco"-. Grasas y Aceites, 45 (5) 313-318.

Horwitz, N. (1980). - "Official methods of analysis of the association of Official analytical chemists»-. AOAC ed (Washington DC) 185-186.

Montaño-Asquerino, A., Rejano-Navarro, L. and SánchezGómez, A. (1986). - «Proceso rápido de elaboración de aceitunas verdes aderezadas".- Grasas y Aceites 37, 141147.

Sofos, J. N. (1981). - «Nitrite, sorbate and pH interaction in cured meat products"-. Proceedings 34 th annual reciprocal meat conference of the American meat science association. Chicago I. National livestock and Meat board.

Restaino, L. L., Mlenovich, and Bills, S. (1982). - «Effect of acids and sorbate combinations on the growth of four osmophilic yeasts»-. J. Food Protec. 45, 1138-1142.

Sofos, J. N., and Busta, F. F. (1982). - «Antimicrobial activity of sorbic acid»-. J. Food. Prot. 44, 614-622.

Tantaoui-Elaraki A. and Letutour B. (1985). - «Contamination des olives et dérivés par les mycotoxines: le point»-. Oléagineux 40, 451-454.

Zamora, R. A., and Zaritsky N. E. (1987). -«Potassium sorbate inhibition of microorganisms growing on refrigerated packaged beef».- J. of Food Sci. 52, 257-262.

Recibido: Julio 1996 Aceptado: Marzo 1997 